Available online on 15.04.2020 at http://jddtonline.info
Open Access to Pharmaceutical and Medical Research
unrestricted non-commercial use, provided the original work is properly cited

Open $\odot$ Access

Research Article

\title{
Inhibition of Pro-Inflammatory Molecules by Ginger (Zingiber officinale Roscoe) and its Anti-Inflammatory Effects on Arthritis Patients
}

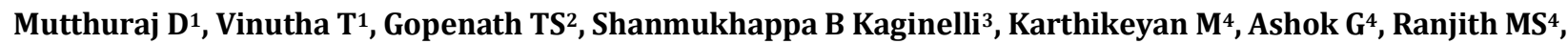 \\ Pradeep Palanisamy ${ }^{5}$ and Kanthesh M Basalingappa ${ }^{*}$
}

1. Division of Molecular Biology, Faculty of Life Sciences, JSS Academy of Higher Education and Research. (Deemed to be University), SS Nagara, Mysuru-570015, India

2. Division of Biotechnology, Faculty of Life Sciences, JSS Academy of Higher Education and Research. (Deemed to be University), SS Nagara, Mysuru-570015, India

3. Division of Medical Physics, Faculty of Life Sciences, JSS Academy of Higher Education and Research. (Deemed to be University), SS Nagara, Mysuru-570015, India

4. Faculty of Medicine, Quest International University Perak, Malaysia

5. Faculty of Medicine, Universiti Kuala Lumpur Royal College of Medicine Perak (UniKL RCMP), Malaysia

\begin{abstract}
Herbal medicinal plants are used to treat various disorders in many traditional medicinal systems around the world. Usage of this herb found in Indian and Chinese medicinal systems. The availability of ginger herb is Universal these days, where it is cultivated for its underground stem (Pseudo-stem). Most commonly used part is rhizome. This ginger rhizome has many therapeutic uses including anti-inflammatory, antidiabetics, antioxidant, anti-microbial and also curing in vomiting, constipation, indigestion, cold, fever,cough, nausea, reparatory conditions, bronchitis etc., these activities were checked using different solvents of different polarity. Arthritis is known for its extreme joint pain and swelling may be treated by using ginger essential oil extract. It was studied that it has the capacity to reducing the pro-inflammatory molecules by lowering the RA-F, CRP, ESR level in the blood.The essences of ginger are due to the chemicals present in them. The products obtained from the ginger like essential oil and oleoresin are used all around the world for its food and pharmaceutical properties.The bioactive compounds like [6]- gingerol and its dehydrated form [6]- shogaol can inhibits the production of free radicals and oxidative stress, along with this properties it can reduce the pro-inflammatory molecules like prostaglandins by inhibiting COX-1 and COX-2.It also observed by the recent studies that the ginger and its extract have the capacity of suppressing the leukotriene biosynthesis by inhibiting 5 -lipoxygenase. To this effect in-vitro study conducted in the lab shows the maximum inhibition as well as maximum protection by the ginger essential oil extract. The essential oil extraction were administered external apply and the variation in the certain proteins and inflammation related antibodies were studied.
\end{abstract}

Keywords: Zingiber offcinale, Spice, Arthritis, Essential oil, Anti-Inflammatory, Gingerol, Shogaol, Auto-Immune Disorders.

Article Info: Received 17 Dec 2019; Review Completed 20 Feb 2020; Accepted 08 April 2020; Available online 15 April 2020

Cite this article as:

Mutthuraj D, Vinutha T, Gopenath TS, Kaginelli SB, Karthikeyan M, Ashok G, Ranjith MS, Palanisamy P, Basalingappa KM, Inhibition of Pro-Inflammatory Molecules by Ginger (Zingiber officinale Roscoe) and its Anti-Inflammatory Effects on Arthritis Patients, Journal of Drug Delivery and Therapeutics. 2020; 10(2-s):125-139 http://dx.doi.org/10.22270/jddt.v10i2-s.3963

*Address for Correspondence:

Kanthesh M. Basalingappa, Assistant Professor, Division of Molecular Biology, Faculty of Life Sciences, JSS Academy of Higher Education and Research, (Deemed to be University), SS Nagara, Mysuru-570015

\section{INTRODUCTION}

Ginger is a spice which is commonly used in culinary and medicinal uses since centuries [1]. Ginger herb belongs to the family Zingiberaceae and scientifically known as Zingiber officinale is one of the most widely used spices around the world [2].William Roscoe (1753-1831) he gave the name ginger which is based on the Sanskrit word "Singabera" which means having a shape of horn due to the projection of the rhizome. This herb is widely cultivated around India, South-East Asia, Africa, Latin America and Australia [3]. It's known that ginger has been continuously used in Indian and Chinese traditional medicine for the past 25 centuries [4]. Ginger has been all around the world for their richness in medicinal and health benefits and used in all most all medicinal systems [5]. The ginger rhizome is commonly used 
as ginger paste, powder, or in the form of flavouring agent in tea [6]. Ginger is a herbaceous plant which widely found in the region of tropical areas and usually grows well in hot and steamy environment. India is major country in production of Zingiber officinale [7]. Ginger is studied for its medicinal properties and its effects as antimicrobial, anti-diabetic, nephroprotective, hepatoprotective, anti-inflammatory, anticancerous, and for its immunomodulatory activities [8].The herb typically belongs to warm climatic conditions where it is extensively cultivated around India, China, Jamaica, Mexico, Africa, Hawaii. Products like essential oil and oleoresin of Zingiber officinale are hugely commercialized internationally for its use in food and pharmaceutical industries [9].

Plants are the best source for its ability to treat certain disorders with fewer side effects; some of the modern medications were being isolated from these types of herbal pants [10]. Traditional medicinal plants are cheaper and easily available for preparing medicinal extract from them. Medicinal herbs are commonly referred as "Chemical Goldmines" due to their properties containing natural chemicals for medicinal use [11].

Ginger is known for its strong aroma and flavour. Properties like antibacterial, antiviral, antifungal, anti-inflammatory properties are found in ginger essential oil. The pharmacological activity of ginger essential oil have to found in having antioxidant, anti-inflammatory and antinociceptive properties [12]. Over the past 25 centuries ginger and its extract is being used as for its medicinal properties, it is used to reduce the level of cholesterol and a body warming agent. US - FDA recognised ginger and its extract as generallyrecognized as safe (GRAS), but recent studies showing its efficiency in medicinal system [13].

Presently, interest in herbal medicinal plants have got much importance, several scientific investigation carried out to identify and isolation of such active compounds present in the ginger various pharmacological studies have shown its active constituent and its inhibiting several diseases and conditions [14].

Ginger having that strong aroma is due to the presence of pungent compounds like ketones compounds as gingerol a primary compound is the major constituent for its aroma. The herb cultivated and consumed all around the world, the consumed part commonly known as "ginger root" even though it's not a root [15].

The bioactive compound present in ginger are commonly volatile in nature at room temperature thus, they are known by the name essential oil, volatile oil and ethereal oils [16]. Most abundantly available compound in the ginger extract is
[6]- gingerol, shogaols which is the dehydration product of gingerol [17]. Cookies, candy, teas, tinctures, sodas, jam, beer, capsule and syrup are the commercially available ginger products. Past obtained from ginger can be administered by applying it in the form of fresh paste, ginger tea (flavouring), dried power and as preserved slices [18].

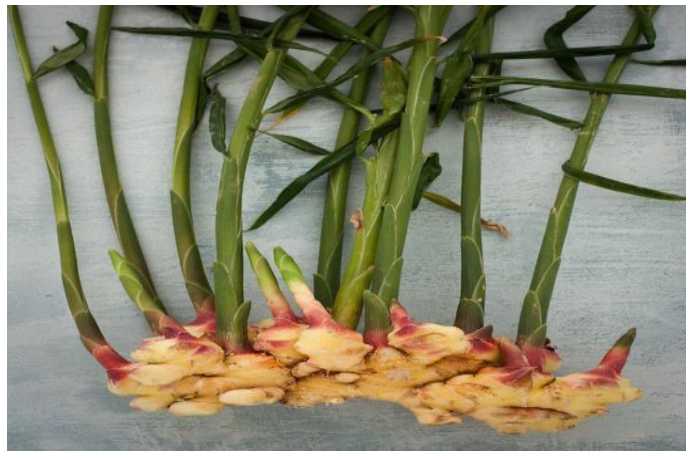

Figure1: Ginger rhizome

\section{Objective of the Study}

The main objectives/Aim of this pilot study are:-

- $\quad$ Phytochemical screening of fresh and dry ginger and its essential oil.

- Detection of total phenolics and flavanoids content in the ginger essential oil.

- Anti-inflammatory assay (Membrane stabilizing activity) carried out to check ginger essential oils effect as an anti-inflammatory agent.

\section{Hypothesis of the Study}

The extracted ginger essential oil from both fresh and dry ginger is having a greater potential in curing many ailments; specifically it may reduce the pro-inflammatory molecule such as, prostagalandins and leukotriene by inhibiting or suppressing the biosynthesis of COX -1 , COX -2 and 5lipoxygenase respectively.

\section{MATERIALS AND METHODS}

\section{Collection of Ginger rhizome}

Both fresh and dry ginger was purchased from the local Mandya market was selected for this experiment. The ginger rhizome washed with the tap water removing stone, dust and other waste matter. The cleaned fresh ginger rhizome chopped in to $1 \mathrm{~mm}$ sized pieces, and dry ginger were powered in electric mixer was used. The chopped and powered ginger rhizomes were kept at $4{ }^{\circ} \mathrm{C}$ to avoid contamination till further use.
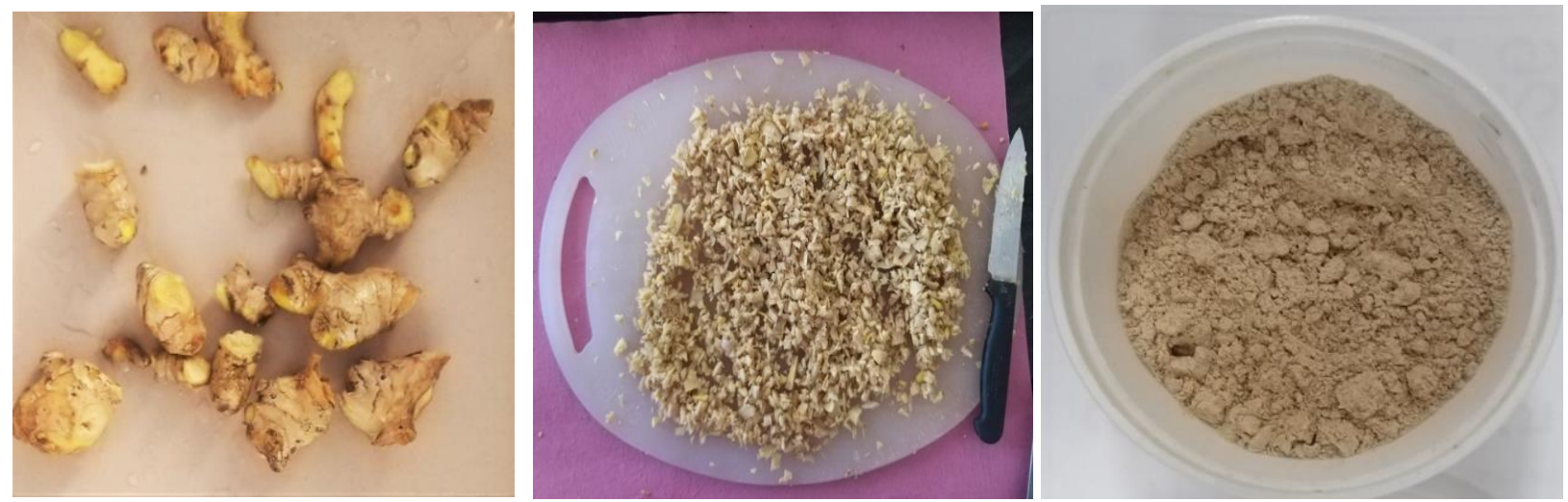

Figure 2: Ginger rhizome, freshly chopped and dried ginger rhizome 


\section{Preparation of ginger essential oil extract:}

Fresh and dry ginger rhizome was taken, and the essential oil was extracted by using soxhlet extractor with optimal conditions. $50 \mathrm{~g}$ of fresh and dry ginger was used with $200 \mathrm{ml}$ of different solvents such as, Acetone, ethyle acetate, ethanol, methanol, chloroform, aqueous. The operating temperature for this experiment carried out varied from $30^{\circ} \mathrm{C}$ to $40^{\circ} \mathrm{C}$. The obtained sample distilled to recover solvent at $10^{\circ} \mathrm{C}$ until all the solvents were collected in the thimble and leaving behind ginger essential oil in the distillation flask. The obtained ginger essential oil was collected and stored in the room temperature for further use. The extraction done for all the six solvents and their yields were noted [19].

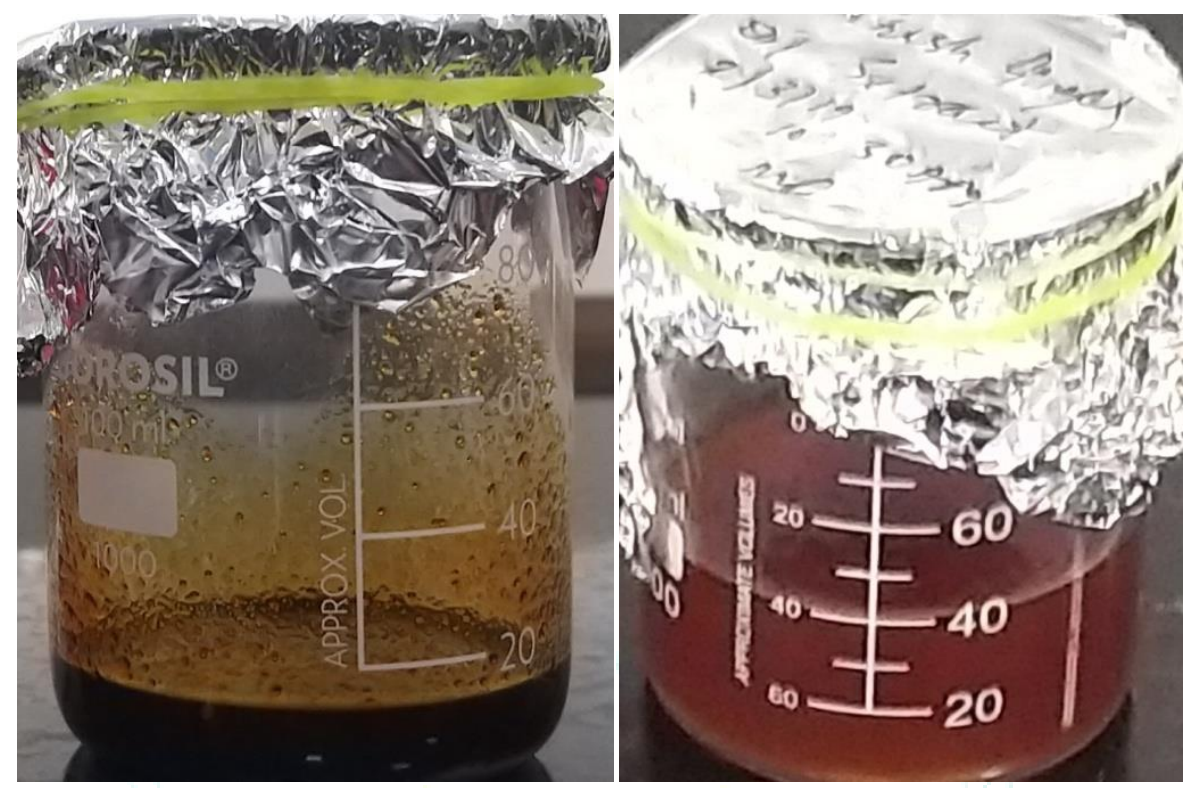

Figure 3: Dry and fresh ginger essential oil extract

\section{HPLC analysis of ginger essential oil extract:}

The obtained ginger oil acetone extract was centrifuged for 5 min at $3000 \mathrm{rpm}$ and the sample were checked for its OD by using UV-Spectrophotometer to send to HPLC. The bioactive compounds present in the ginger oil were examined by using HPLC system. The stationary phase used was Sunfire- C18, with particle size $5 \mu \mathrm{m}$, pre-packed in a $4.6 \times 250 \mathrm{~mm}$ I.D column. The mobile phase used was Acetonitrile with $0.1 \%$ Formic acid in Water. With the flow rate of $1 \mathrm{ml} / \mathrm{min}$. Acetonitrile was carried by the pump. An injector with $10 \mu \mathrm{l}$ loop was used for injecting the sample. This analysis was carried out at optimal temperature. Photo diode array detector with254nm was used for the analysis [20].

\section{SEM analysis of ginger extract:}

SEM analysis was carried out to understand the morphology of ginger powder. The ginger was extracted by using aqueous solvent. $40 \mathrm{ml}$ of silver nitrate mixed with $10 \mathrm{ml}$ of aqueous extract of ginger powder. This process was done by using magnetic stirrer and heating methods. The sample were mixed and stirred for 1.5 hrs till the colourchanges from yellow to brown. In heat method the sample was mixed as stated above and heated in the water bath at $80^{\circ} \mathrm{C}$ till the colour changes from yellow to dark brown. Sample was sent to SEM analysis. The SEM imaging was accomplished by freeze drying the sample and centrifuge at $5000 \mathrm{rpm}$ for 5 min before analysis. For SEM analysis ZEISS/EVO LS 15GERMANY scanning electron microscope were employed at $15 \mathrm{kV}$. The sample was mounted on the aluminium holder stubs using a double sticky carbon tape and coated with $\mathrm{Au} / \mathrm{Pd}$ in a BIORAB Polaron E5400 high resolution sputter coater, and examined in a ZEISS scanning microscope [21]

\section{Qualitative Analysis}

Qualitative analysis was done using both fresh and dry ginger rhizome extracted by using different solvents in soxhlet extractor [22]. 
Table 4: Procedure for qualitative analysis of ginger essential oil extract

\begin{tabular}{|c|c|c|c|}
\hline $\begin{array}{l}\text { PHYTOCHEMICAL } \\
\text { TESTS }\end{array}$ & TEST NAME & PROCEDURE & INFERENCE \\
\hline ALKOLOIDS & WAGNER'S TEST & $\begin{array}{l}\text { 0.5ml EXTRACT + FEW DROPS OF } \\
\text { dil HCL + FEW DROPS OF MAYER'S } \\
\text { REAGENT }\end{array}$ & REDDISH BROWN PRECIPITATE \\
\hline CARBOHYDRATES & MOLISH TEST & $\begin{array}{l}0.5 \mathrm{ml} \text { EXTRACT }+2 \text { DROPS OF } \\
\text { MOLISH REAGENT }+\alpha-N A P H T H O L \\
+0.2 \mathrm{ml} \mathrm{H} 2 \mathrm{SO} 4 \text { (Conc) }\end{array}$ & VIOLET RING AT JUNCTION \\
\hline PHLOBOTANNINS & & 0.5ml EXTRACT + 1\% HCL + BOIL & RED PRECIPITATE \\
\hline STEROIDS & SALKOWSKI TEST & $\begin{array}{l}0.5 \mathrm{ml} \text { EXTRACT }+2 \mathrm{ml} \mathrm{OF} \\
\text { CHLOROFORM }+2 \mathrm{ml} \text { OF H2SO } 4+ \\
\text { ADDD BY THE SIDE OF THE TEST } \\
\text { TUBE }\end{array}$ & $\begin{array}{l}\text { VIOLET/BLUE/GREEN/REDDISH } \\
\text { BROWN RING COLOUR APEARS }\end{array}$ \\
\hline TERPENOIDS & SALKOWSKI TEST & $\begin{array}{l}0.5 \mathrm{ml} \text { EXTRACT }+2 \mathrm{ml} \text { OF } \\
\text { CHLOROFORM }+2 \mathrm{ml} \text { OF H2SO }+ \\
\text { ADDD BY THE SIDE OF THE TEST } \\
\text { TUBE }\end{array}$ & $\begin{array}{l}\text { VIOLET/BLUE/GREEN/REDDISH } \\
\text { BROWN RING COLOUR APEARS }\end{array}$ \\
\hline FLAVONOIDS & $\begin{array}{l}\text { ALKALINE } \\
\text { REAGENT TEST }\end{array}$ & $\begin{array}{l}\text { 0.5ml EXTRACT +3ml 10\% NaOH+ } \\
\text { dil, HCL }\end{array}$ & $\begin{array}{l}\text { YELLOW COLOUR BECOMES } \\
\text { COLORLESS }\end{array}$ \\
\hline ANTHRAQUINONES & & $\begin{array}{l}0.5 \mathrm{ml} \text { EXTRACT }+5 \mathrm{ml} \\
\text { CHLOROFORM SHAKE FOR } 5 \mathrm{~min}+ \\
\text { FILTERED + } 2 \mathrm{ml} \text { OF } 10 \% \\
\text { AMMONIUM HYDROXIDE }\end{array}$ & $\begin{array}{l}\text { RED OR VIOLET COLOR AT THE } \\
\text { UPPER LAYER }\end{array}$ \\
\hline REDUCING SUGAR & BENEDICT'S TEST & $\begin{array}{l}\text { EQUAL VOLUME OF BENEDICT } \\
\text { REAGENT + EXTRACT + 5-10min } \\
\text { HEAT }\end{array}$ & $\begin{array}{l}\text { GREEN OR YELLOE OR RED } \\
\text { PRECIPITATE }\end{array}$ \\
\hline AMINO ACIDS & NINHYDRIN TEST & $\begin{array}{l}\text { 0.5ml EXTRACT + 3DROPS OF 5\% } \\
\text { NINHYDRIN REAGENT + HEAT }\end{array}$ & BLUE COLOR \\
\hline GLYCOSIDES & $\begin{array}{l}\text { KELLER-KILIANIN } \\
\text { TEST }\end{array}$ & $\begin{array}{l}\text { 0.5ml EXTRACT + 0.3ml GLACIAL } \\
\text { ACITIC ACID + } 3 \text { DROPS OF FeCl3 + } \\
\text { 1ml OF H2SO4 (conc) }\end{array}$ & $\begin{array}{l}\text { FORMATION OF REDDISH } \\
\text { BROWN COLOR AT THE } \\
\text { JUNCTION OF TWO SOLUTIONS }\end{array}$ \\
\hline PHENOLS & FeCl3 TEST & $\begin{array}{l}\text { 0.5ml EXTRACT + } 3 \text { DROPS OF dist } \\
\mathrm{H} 2 \mathrm{O}+0.5 \mathrm{ml} \text { OF FeCl3 }\end{array}$ & $\begin{array}{l}\text { BLUE OR GREEN OR VIOLET } \\
\text { COLOR }\end{array}$ \\
\hline TANNINS & BIURET TEST & $\begin{array}{l}0.5 \mathrm{ml} \text { EXTRACT }+10 \% \mathrm{NaOH}+2 \\
\text { DROPS OF } 05 \% \text { OF CuSO } 4+\mathrm{HEAT}\end{array}$ & VIOLET COLOR \\
\hline SAPONINS & FOAM TEST & $\begin{array}{l}2 \text { ml EXTRACT + } 2 \text { ml dist } \mathrm{H} 2 \mathrm{O}+ \\
\text { HEAT }\end{array}$ & FORTH APPEARS \\
\hline VOLATILE OILS & OIL TEST & $\begin{array}{l}0.5 \mathrm{ml} \text { EXTRACT + } 2 \mathrm{ml} \text { ETHANOL } \\
\text { MIXED + FEW DROPS OF FERRIC } \\
\text { CHLORIDE }\end{array}$ & $\begin{array}{l}\text { UPPER LAYER APPERS GREEN } \\
\text { COLOR }\end{array}$ \\
\hline CHALCONE & & $\begin{array}{l}0.5 \mathrm{ml} \text { EXTRACT }+2 \mathrm{ml} \text { OF } 1 \% \\
\text { AMMONIUM HYDROXIDE+ MIX } \\
\text { WELL }\end{array}$ & REDDISH COLOR \\
\hline BALSAMS & & $\begin{array}{l}\text { 0.5ml EXTACT + 2ml OF ETHANOL } \\
\text { + MIXED WELL + } 2 \text { DROPS OF } \\
\text { ALCOHOLIC FERRIC CHLORIDE }\end{array}$ & DARK GREEN COLOR \\
\hline RESINS & & $\begin{array}{l}\text { 0.5ml EXTRACT + 2ml OF ACETIC } \\
\text { ANHYDRIDE }+2 \mathrm{ml} \mathrm{OF} \mathrm{H2SO} 4 \\
\text { (conc) }\end{array}$ & PURPLE OR VIOLET COLOR \\
\hline
\end{tabular}




\section{Determination of total phenolics and flavonoid content:}

The determination of total phenolic content present in the ginger essential oil extract was carried out by using $5 \mathrm{ml}$ Folin-Ciocalteu regent mixed with the extract sample. The reagent diluted with water 1:10 ratio with $10 \%$ sodium carbonate. All the reagents and chemicals are mixed and vortexes for $1 \mathrm{~min}$ and allowed to stand for colour development for $30 \mathrm{~min}$ in room temperature later the absorbance was measured with $720 \mathrm{~nm}$ using UVSpectophotometer. The total phenolic content was expressed as Gallic acid equivalents $(\mathrm{mg} / \mathrm{g})$. The sample was measured for conectration of $10,50,100,250,500 \mu l$ and the obtained concentration of total phenolic content was 2 and $4 \mathrm{mg} / \mathrm{ml}$ in fresh ginger and 3 and $7 \mathrm{mg} / \mathrm{ml}$ in dry ginger extract.

The total flavonoid content was measured by taking the 100 and $250 \mu \mathrm{l}$ of sample with same ratio of sodium nitrate, $2 \%$ aluminium chloride and sodium hydroxide with distilled water and kept for incubation at room temperature for $10 \mathrm{~min}$. After one hour the absorbance was measured at $510 \mathrm{~nm}$. The total flavonoid content was expressed as quercetin $(\mathrm{mg} / \mathrm{ml})$. The obtained concentration of total flavonoid content was 3 and $8 \mathrm{mg} / \mathrm{ml}$ in fresh ginger 4 and $8 \mathrm{mg} / \mathrm{ml}$ in dry ginger extract [23].

\section{Determination of invitro anti-inflammatory activity}

\section{Membrane stabilization assay}

\section{Preparation of Red Blood Cells (RBC):}

The blood was collected from the healthy volunteer who was not on any anti-inflammatory drugs. The $5 \mathrm{ml}$ blood collected was transferred to the $15 \mathrm{ml}$ centrifuge tubes. The tubes were centrifuged at $3000 \mathrm{rpm}$ for $10 \mathrm{~min}$. The plasma was removed and the precipitated RBC suspension was washed with normal saline $(\mathrm{NaCl})$ three times.

\section{Heat induced haemolysis:}

Taking $1 \mathrm{ml}$ of sample of different concentration from 100 to $500 \mu \mathrm{g} / \mathrm{ml}$ and $1 \mathrm{ml}$ of $\mathrm{RBC}$ suspension making $2 \mathrm{ml}$ of reaction mixture. In the control test tube only saline was added. Aspirin was used as a standard drug. The tubes were later incubated in water bath at $50^{\circ} \mathrm{C}$ for $30 \mathrm{~min}$ the tubes kept for cooling under running water. Again the mixture was centrifuged at $2500 \mathrm{rpm}$ for $5 \mathrm{~min}$ and absorbance of the supernatants was measured at $520 \mathrm{~nm}$

The percentage inhibition of haemolysis was calculated by using

Percentage inhibition $=\frac{(\text { Abs control }- \text { Abs sample })}{A b s \text { control }} \times 100$

\section{Hypotonicity induced haemolysis}

Membrane stabilizing activity of extract was assessed using hypotonic solution - induced 6human erythrocytes haemolysis. The test sample consists of RBC suspension $(0.5 \mathrm{ml})$ mixed with $5 \mathrm{ml}$ of hypotonic solution $(50 \mathrm{mM} \mathrm{NaCl})$ in $10 \mathrm{mM}$ phosphate buffer solution ( $\mathrm{pH}=7.4)$ containing the extract $(10 \mathrm{mg} / \mathrm{ml})$ or diclofenac sodium $(10 \mathrm{mg} / \mathrm{ml})$. The control tube consists of $0.5 \mathrm{ml}$ of RBC mixed with hypotonic buffered saline solution alone. The mixture were incubated for $10 \mathrm{~min}$ at room temperature and centrifuged for $10 \mathrm{~min}$ at $3000 \mathrm{rpm}$ abd absorbance of the supernatant was measured at $560 \mathrm{~nm}$ [24].

Percentage of membrane stabilizing activity was calculated by using

$$
\text { Percentage protection }=100-\frac{(\text { OD of sample })}{(\text { OD of control })} \times 100
$$

\section{Preparation of dosage of ginger essential oil}

Ginger essential oil (Fresh and dry) was tested for its antiinflammatory activity in arthritis affected volunteers. The extracted ginger oil from soxhlet extractor was mixed with the carrier oil (coconut oil, Vaseline, alovera gel, Castrol oil etc.) to dilute the concentration in the crude ginger oil extract. In this pilot study coconut oil was used as carrier oil. The dilution of ginger crude extracted oil was done by using the following chart.

\begin{tabular}{|l|l|l|l|l|l|l|}
\hline \multicolumn{7}{|c|}{ Essential Oil Dilution Chart } \\
nourishingtreasures.com/EOdilutions \\
\hline Dilution & $\mathbf{1} \%$ & $\mathbf{2} \%$ & $\mathbf{3} \%$ & $\mathbf{5 \%}$ & $\mathbf{1 0} \%$ & $\mathbf{2 5} \%$ \\
\hline $\begin{array}{l}\text { drops of EO for } \mathbf{1} \text { tsp }(5 \mathrm{ml} ; \\
1 / 6 \text { oz.) carrier oil }\end{array}$ & 1 & 2 & 3 & 5 & 10 & 25 \\
\hline $\begin{array}{l}\text { drops of EO for } \mathbf{2} \text { tsp }(10 \mathrm{ml} ; \\
1 / 3 \text { oz.) carrier oil }\end{array}$ & 2 & 4 & 6 & 10 & 20 & 50 \\
\hline $\begin{array}{l}\text { drops of EO for } \mathbf{3} \text { tsp }(15 \mathrm{ml} ; \\
1 / 2 \text { oz.) carrier oil }\end{array}$ & 3 & 6 & 9 & 15 & 30 & 75 \\
\hline $\begin{array}{l}\text { drops of EO for } \mathbf{4} \text { tsp }(20 \mathrm{ml} ; \\
2 / 3 \text { oz.) carrier oil }\end{array}$ & 4 & 8 & 12 & 20 & 40 & 100 \\
\hline $\begin{array}{l}\text { drops of EO for } \mathbf{5} \text { tsp }(25 \mathrm{ml} ; \\
5 / 6 \text { oz.) carrier oil }\end{array}$ & 5 & 10 & 15 & 25 & 50 & 125 \\
\hline $\begin{array}{l}\text { drops of EO for } \mathbf{6} \text { tsp (30ml; } \\
1 \text { oz.) carrier oil }\end{array}$ & 6 & 12 & 18 & 30 & 60 & 150 \\
\hline
\end{tabular}

Figure 4: Dilution chart for ginger essential oil with carrier oil

Along with the essential oil (fresh and dry), freshly prepared ginger medicine was used in the study. The freshly prepared ginger remedy includes finely chopped $10 \mathrm{~g}$ of ginger was pasted in the mixer to this 2 whole clove of garlic was added along with 1 tbls of sea salt was added and mixed properly and kept in room temperature for future use.

\section{Dosage of ginger essential oil}

The dosage administered by the dilution of the extracted oil, where the essential oil with carrier oil mixture was given in different concentration throughout a month long period. During the first 10 days the concentration of both fresh and dry ginger oil was limited to $1 \%$ and later increased to $5 \%$ 
and $10 \%$ in the next 20 and 30 days respectively. And the ginger freshly prepared remedy was applied for $6 \mathrm{hrs}$ to see the results accordingly. All the ginger essential along with freshly prepared ginger medicinal remedy was administered externally for 30 days.

The body fluid (Blood) was sent for laboratory test to see the before and after affects of administering ginger essential oil and freshly prepared ginger medicinal remedy. The laboratory test carried in this pilot study were Haemoglobin (M 12-16 g\% , F 12-14 g\%), ESR (M 10-20 $\mathrm{mm} / \mathrm{hrs}$, F $10-40 \mathrm{~mm} / \mathrm{hrs})$, Blood sugar $(80-140 \mathrm{mg} / \mathrm{dl})$, Albumin (3.5-5.2 gm/dl), Uric Acid (2.7 gm/dl), RA (20 $\mathrm{IU} / \mathrm{ml})$, ASLO (5-200 IU/ml), CRP $(<0.5-3.0 \mathrm{mg} / \mathrm{dl})$.

\section{RESULTS:}

The fresh and dry ginger essential oil extraction extracted by using soxhlet extractor, yield (ml) was tabulated as below:

\section{Solvent extraction from fresh and dry ginger:}

The extraction of fresh and dry ginger done by using soxhlet extractor. The yield obtained was noted. The solvents used for the extracting essential oil are -Polar solvents: - Water, Methanol, Ethanol, Dipolar solvents: - Acetone, Ethyle acetate, Non-polar solvent: - Chloroform. The maximum yield obtained under optimal temperature by using bipolar solvent acetone which yields up to 19 and $21 \mathrm{ml}$ respectively.

Table 5: Yield of fresh and dry ginger essential oil in different solvents

\begin{tabular}{|c|c|c|}
\hline SOLVENT USED & FRESH GINGER OIL YIELD IN ml & DRY GINGER OIL YIELD IN ml \\
\hline Acetone & 19 & 21 \\
\hline Ethyle acetate & 06 & 05 \\
\hline Chloroform & 09 & 07 \\
\hline Methanol & 08 & 06 \\
\hline Ethanol & 10 & 05 \\
\hline Aqueous & 03 & \\
\hline
\end{tabular}

\section{HPLC}

HPLC analysis carried out to determine whether there is a presence of polyphenolic bioactive compounds. The analysis showed that the presence of [6]-gingerol and its hydrated components in the ginger essential oil. The HPLC analysis result shows that the presence of specific compound [6]gingerol and its hydrated polyphenolic compounds in the essential oil sample. This has been compared with the standard and the retention time of [6]-gingerol is $4.40 \mathrm{~min}$ noted at its maximum peek time under optimal conditions.

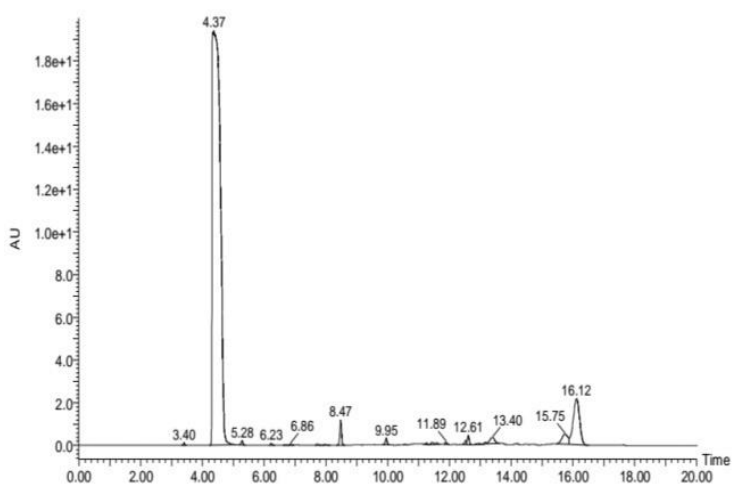

A. Fresh Ginger essential oil

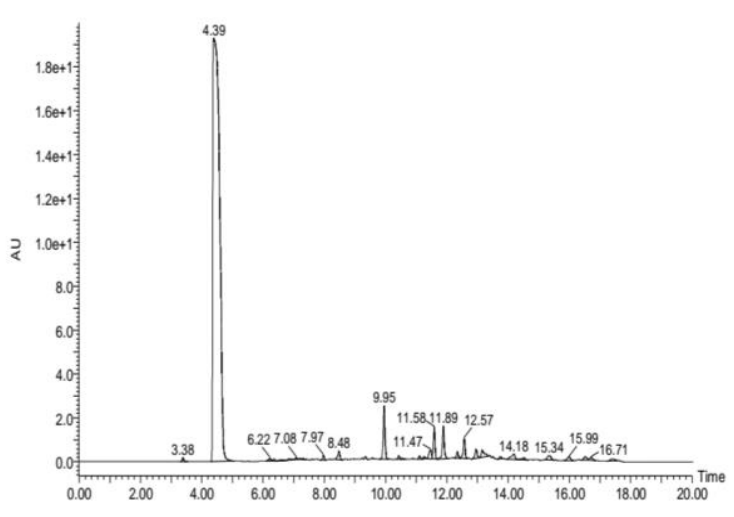

B. Dry Ginger essential oil

Figure 5: HPLC chromatograms of acetone extract peek showing the gingrol and its hydrated polyphenolic bioactive components.

\section{SEM analysis report:}

Ginger essential oil was analysis by using scanning electron microscope [SEM]. This analysis shows the detail size and morphology of the silver binding to the ginger extract. In ginger extract prepared by using magnetic stirrer the particle size of silver nanoparcticle was $234.4 \mathrm{~nm}$. And by applying heat to the ginger sample the particle size of silver nanoparticle binded to the sample was $530.8 \mathrm{~nm}$. 


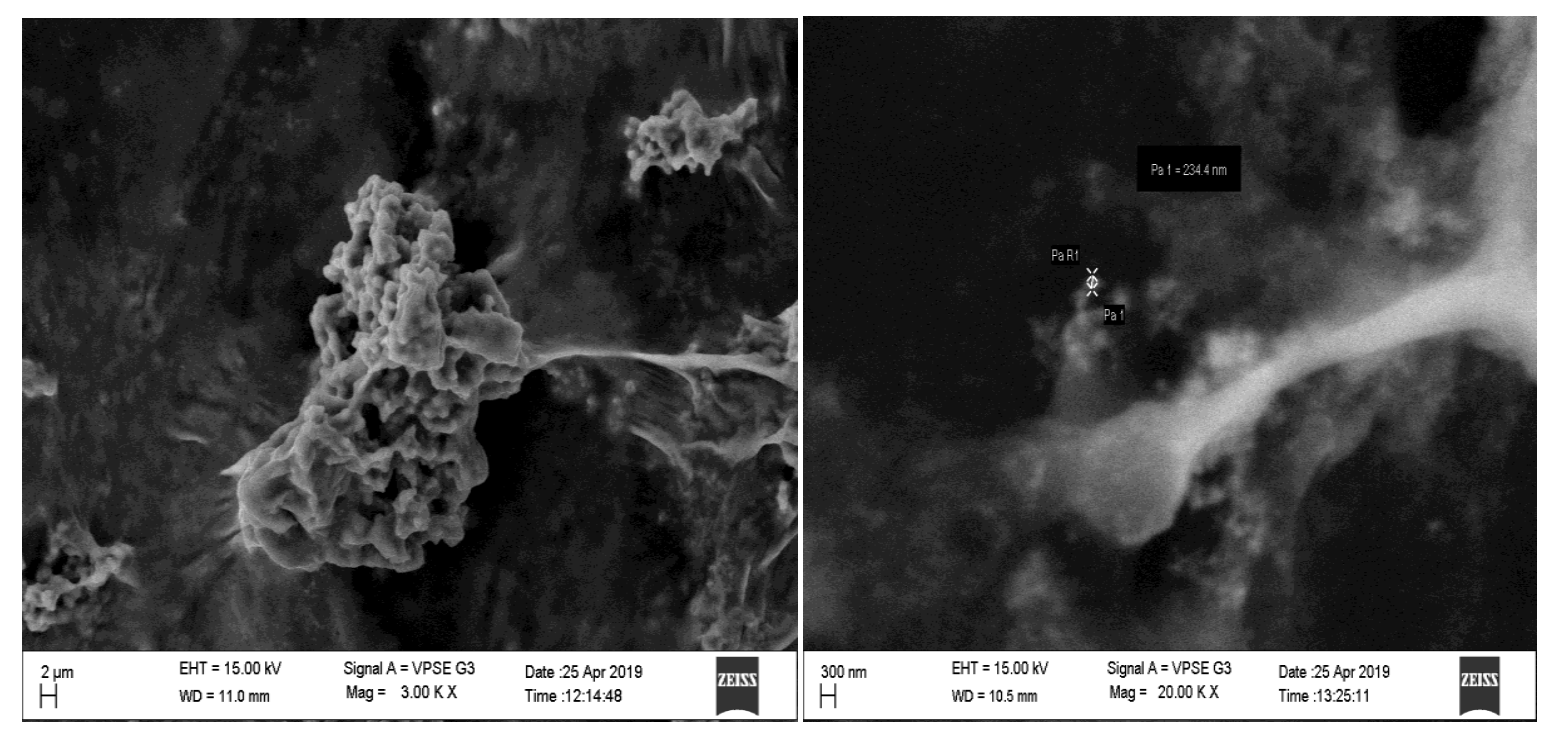

A. GINGER EXTRACT OF SILVER NANOPARTICLE PREPARED USING MAGNETIC STIRRERMETHOD

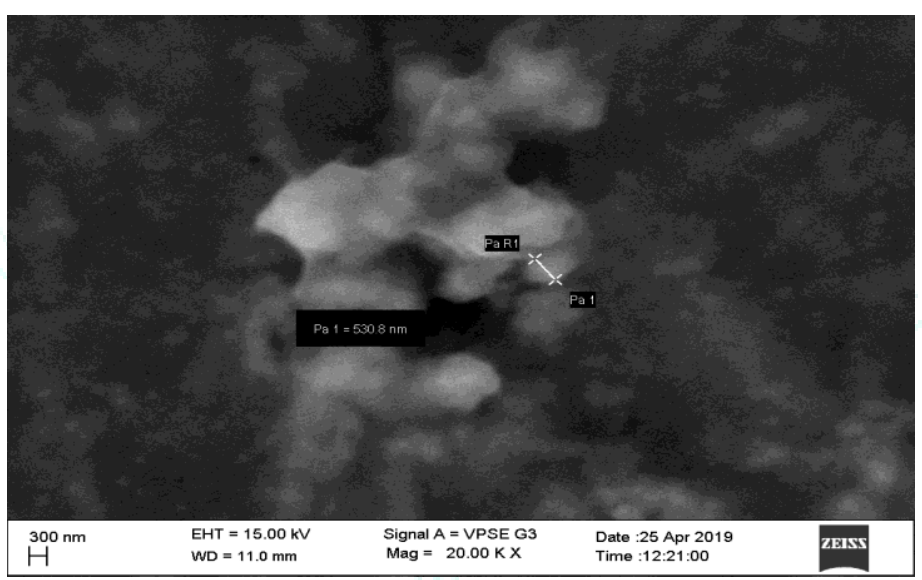

B. GINGER EXTRACT SILVER NANOPARTICLE PREAPRED USING HEAT METHOD

Figure 6: SEM analyses of aqueous extract of ginger done by using zeiss scanning microscope in 3.00K X, AND 20.00K X magnification respectively shows the ginger extract affinity towards the silver nanoparticls.

\section{Phytochemical analysis report:}

Phytochemical screenings of both fresh and dry ginger essential oil were showed the rich phytochemistry present in the ginger. By using different solvents analysis was carried out to know the active component of the ginger.
Alkaloids, polyphenolics, flavonoids, volatile oils, glycosides, carbohydrates, were shown presence in all most all the solvents but lacks bioactive compounds like phlobotannins, anthraquinone etc., This shows the phytochemical richness of the ginger herb. 
Table 6: Phytochemical screening of bioactive compounds present in fresh ginger essential oil extract

\begin{tabular}{|c|c|c|c|c|c|c|c|}
\hline $\begin{array}{c}\text { SL } \\
\text { NO. }\end{array}$ & $\begin{array}{c}\text { Bioactive } \\
\text { Compounds }\end{array}$ & Acetone & $\begin{array}{c}\text { Ethyle } \\
\text { Acetate }\end{array}$ & Methanol & Chloroform & Ethanol & Aqeuous \\
\hline 01. & Alkaloids & + & + & + & + & + & + \\
\hline 02. & Carbohydrate & + & + & + & - & + & - \\
\hline 03. & Phlobotannins & - & - & - & - & - & - \\
\hline 04. & Steriods & - & - & + & + & - & - \\
\hline 05. & Terpenoids & + & + & + & - & - & - \\
\hline 06. & Flavonoids & + & + & + & + & + & + \\
\hline 07. & Anthraquinone & - & - & - & - & - & - \\
\hline 08. & Reducing Sugar & + & + & + & - & + & - \\
\hline 09. & Amino Acid & - & - & - & - & - & - \\
\hline 10. & Glycosides & + & + & + & + & + & + \\
\hline 11. & Phenol & - & + & - & - & - & - \\
\hline 12. & Tanins & - & + & - & - & - & - \\
\hline 13. & Proteins & - & - & - & - & - & - \\
\hline 14. & Saponins & - & - & - & - & - & - \\
\hline 15. & Volatile Oil & - & - & + & - & + & - \\
\hline 16. & Chalcone & + & - & - & + & - & - \\
\hline 17. & Balsams & + & + & - & + & - & - \\
\hline 18. & Resin & + & - & - & - & - & - \\
\hline
\end{tabular}

Table 7: Phytochemical screening of bioactive compounds present in the dry ginger essential oil extract.

\begin{tabular}{|l|c|c|c|c|c|c|c|}
\hline $\begin{array}{c}\text { SL. } \\
\text { NO }\end{array}$ & $\begin{array}{c}\text { Bioactive } \\
\text { Compounds }\end{array}$ & Acetone & $\begin{array}{c}\text { Ethyle } \\
\text { Acetate }\end{array}$ & Methanol & Chloroform & Ethanol & Aqeuous \\
\hline 01. & Alkaloids & + & + & + & + & + & - \\
\hline 02. & Carbohydrate & + & - & - & - & + & + \\
\hline 03. & Phlobotannins & - & + & + & - & - & - \\
\hline 04. & Steriods & - & + & - & - & - & - \\
\hline 05. & Terpenoids & + & + & + & + & + & - \\
\hline 06. & Flavonoids & + & - & + & + & + & + \\
\hline 07. & Anthraquinone & - & - & - & - & - & - \\
\hline 08. & Reducing Sugar & + & - & - & - & + & + \\
\hline 09. & Amino Acid & + & - & - & - & - & - \\
\hline 10. & Glycosides & + & + & + & + & + & + \\
\hline 11. & Phenol & + & + & - & - & - & + \\
\hline 12. & Tanins & - & - & - & - & - & - \\
\hline 13. & Proteins & + & - & - & - & - & - \\
\hline 14. & Saponins & + & - & - & + & - & + \\
\hline 15. & Volatile Oil & + & + & + & + & + & - \\
\hline 16. & Chalcone & - & - & - & - & - & - \\
\hline 17. & Balsams & + & - & - & + & + & + \\
\hline 18. & Resin & - & + & - & + & + & - \\
\hline
\end{tabular}

The presence of different bioactive compounds are observed by using different solvent extrcats. 
Mutthuraj et al

Total phenolics and flavonoids test report

Total phenolics and flavonoids content present in the ginger essential oil were determined by using gallic acid $(\mathrm{GAE} / 100 \mathrm{ml})$ and quercetine $(\mathrm{QE} / 100 \mathrm{ml})$ standard. The
Journal of Drug Delivery \& Therapeutics. 2020; 10(2-s):125-139 results show that the richest phenolics and flavonoids is present in dry ginger. The presence of these bioactive compounds results in the ginger ability to be used as potential herbal medicinal plant.

Table 8: Total phenolics and flavonoids present in the acetone extract of ginger essentical oil

\begin{tabular}{|c|c|c|c|c|}
\hline $\begin{array}{c}\text { CONC. OF SAMPLE } \\
(\boldsymbol{\mu l})\end{array}$ & $\begin{array}{c}\text { FRESH GINGER } \\
\text { TPC }(\boldsymbol{\mu g} / \mathrm{ml})\end{array}$ & $\begin{array}{c}\text { DRY GINGER TPC } \\
(\boldsymbol{\mu g} / \mathrm{ml})\end{array}$ & $\begin{array}{c}\text { FRESH GINGER TFC } \\
(\boldsymbol{\mu g} / \mathrm{ml})\end{array}$ & $\begin{array}{c}\text { DRY GINGER TFC } \\
(\boldsymbol{\mu g} / \mathbf{m l})\end{array}$ \\
\hline 100 & 2 & 3 & 3 & 4 \\
\hline 250 & 4 & 7 & 8 & 8 \\
\hline
\end{tabular}

\section{Membrane stabilization assay}

Membrane stabilizing activity is an in-vitro study to check the $\%$ of inhibition of the sample by using RBC cells. Erythrocyte cell membranes can be comparable to the membrane of lysosome. By stabilization of the RBC cell membrane it interprets that it can also stabilise the lysosomal membrane. The graphs showing that ginger essential oil has the capacity to inhibit the pro-inflammatory molecules which are present in the cell by limiting lysosomal constituents. For heat induced and hypotonicity-induced haemolysis the \% of inhibition obtained was 74.6, 89.6 and 73.68, $84.21(500 \mu \mathrm{l})$ respectively.

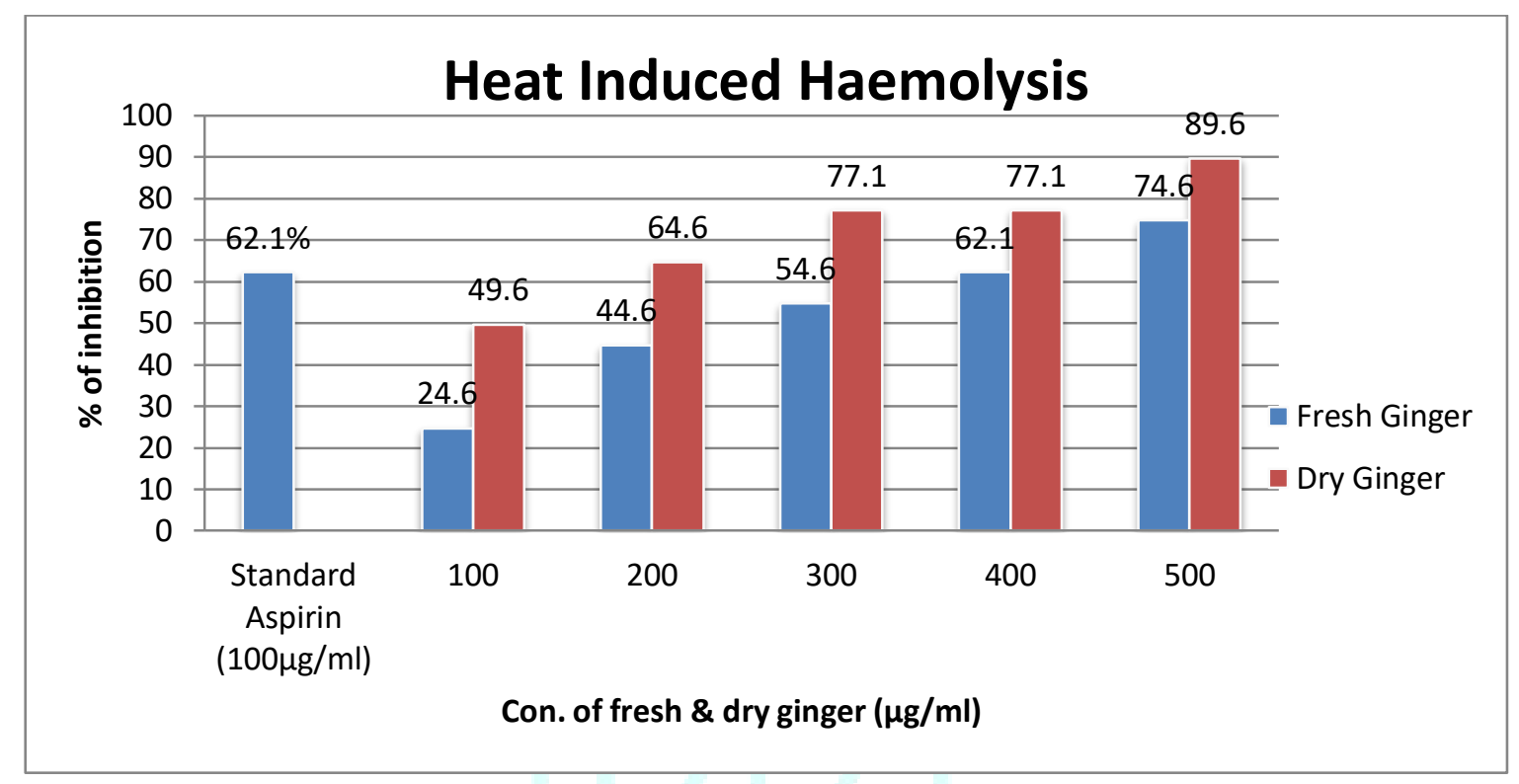

Figure 7: Membrane stabilization of RBC in Heat induced haemolysis by using ginger essential as sample \% of inhibition is shown in the graph.

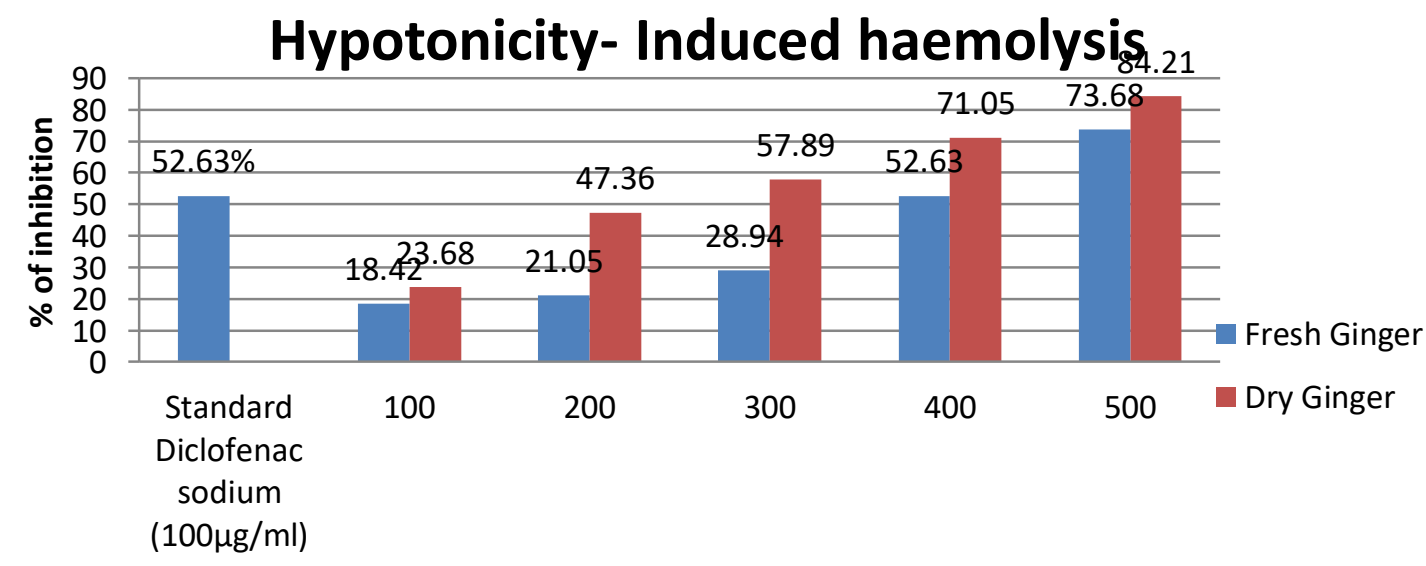

Conc. of fresh \& dry ginger $(\mu \mathrm{g} / \mathrm{ml})$

Figure 8: Hypotonicity-Induced haemolysis assessment of in-vitro anti-inflammtory activity. \% of protection was plotted in the above graph. Both Fig 8 \& 9 showing the in-vitro anti-inflammatory activity of ginger essential oil extract 


\section{Laboratory test results}

\section{HAEMOGLOBIN:}

Haemoglobin is a very important constituent of the blood.

The below graph shows that the varying level of haemoglobin level from $0^{\text {th }}$ day to $30^{\text {th }}$ day in the volunteers affected by arthritis. Normal range of haemoglobin level in normal health person is - Male 12-16 g\%, Female 12-14 g\%.

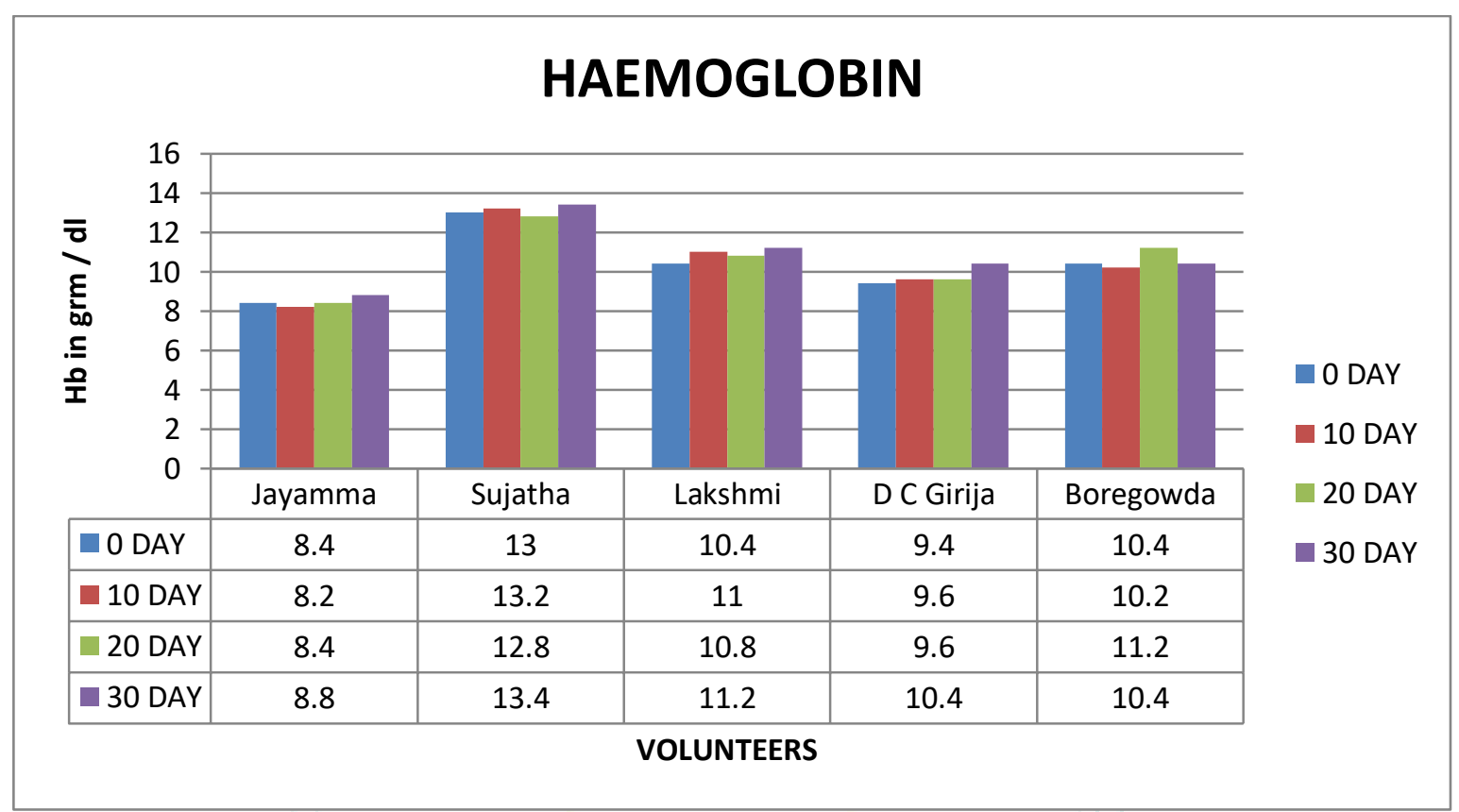

Figure 9: Graph showing haemoglobin level in volunteers suffering from joint pain (Arthritis)

\section{ESR:}

Erythrocyte sedimentation rate (ESR) is a non-specific test done to check the infection, disease or conditions causing inflammation in the body. The below graph shows the decreasing level in the ESR in selected volunteers from $0^{\text {th }}$ day to $30^{\text {th }}$ day. The inflammation reduced week by week by increasing the dosage of ginger essential oil. Normal level of ESR in an healthy individual is -Male $10-20 \mathrm{~mm} / \mathrm{hrs}$, Female $10-40 \mathrm{~mm} / \mathrm{hrs}$.

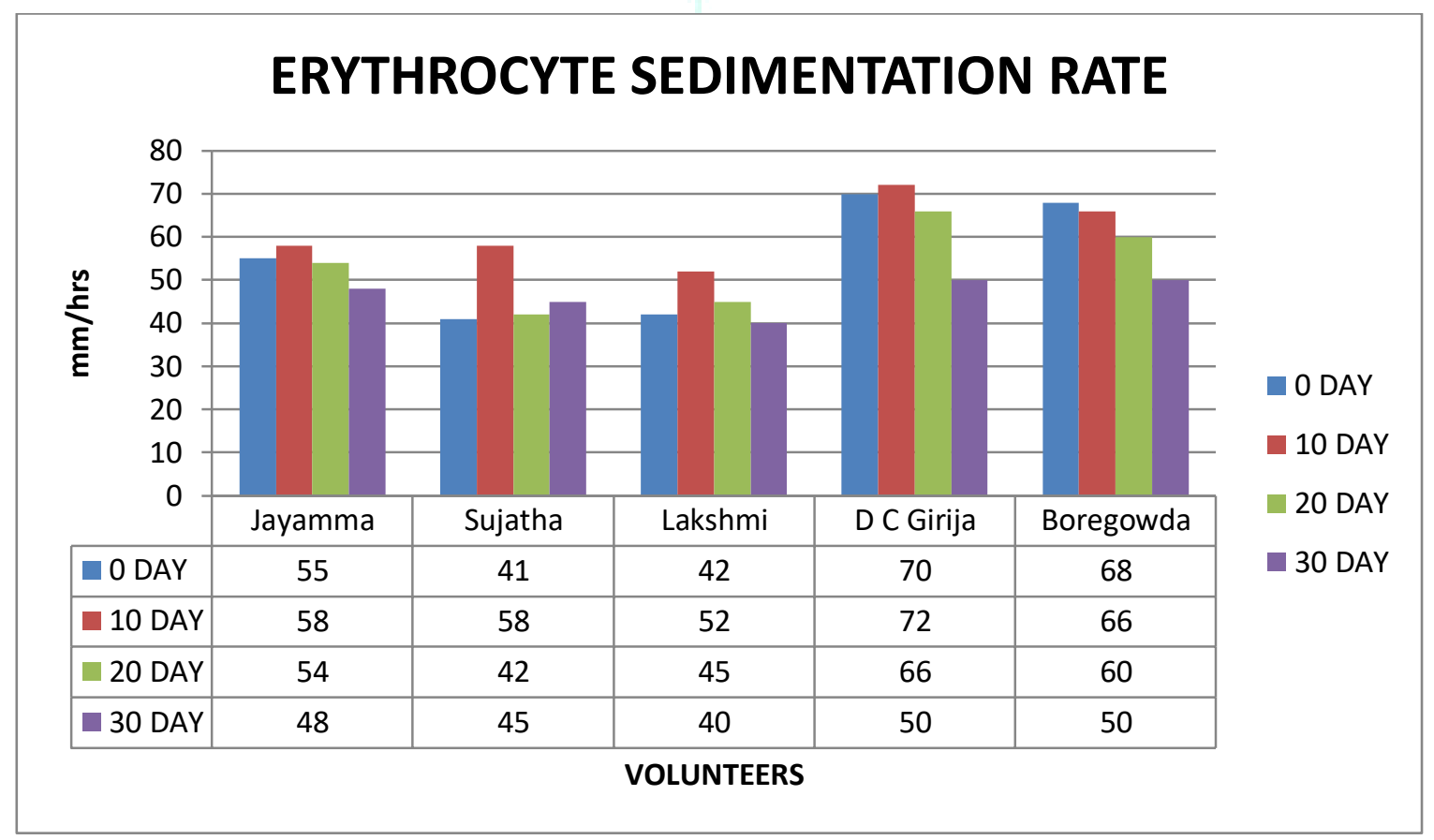

Figure 11: Graph showing in decreasing level of ESR in most of the volunteers 


\section{RANDOM BLOOD SUGAR:}

Random blood sugar level was tested in the volunteers in the $0^{\text {th }}$ day of the pilot study. Only two volunteers were suffering from hyperglycaemic condition and all others were found be to in normal range $(80-140 \mathrm{mg} / \mathrm{ml})$.

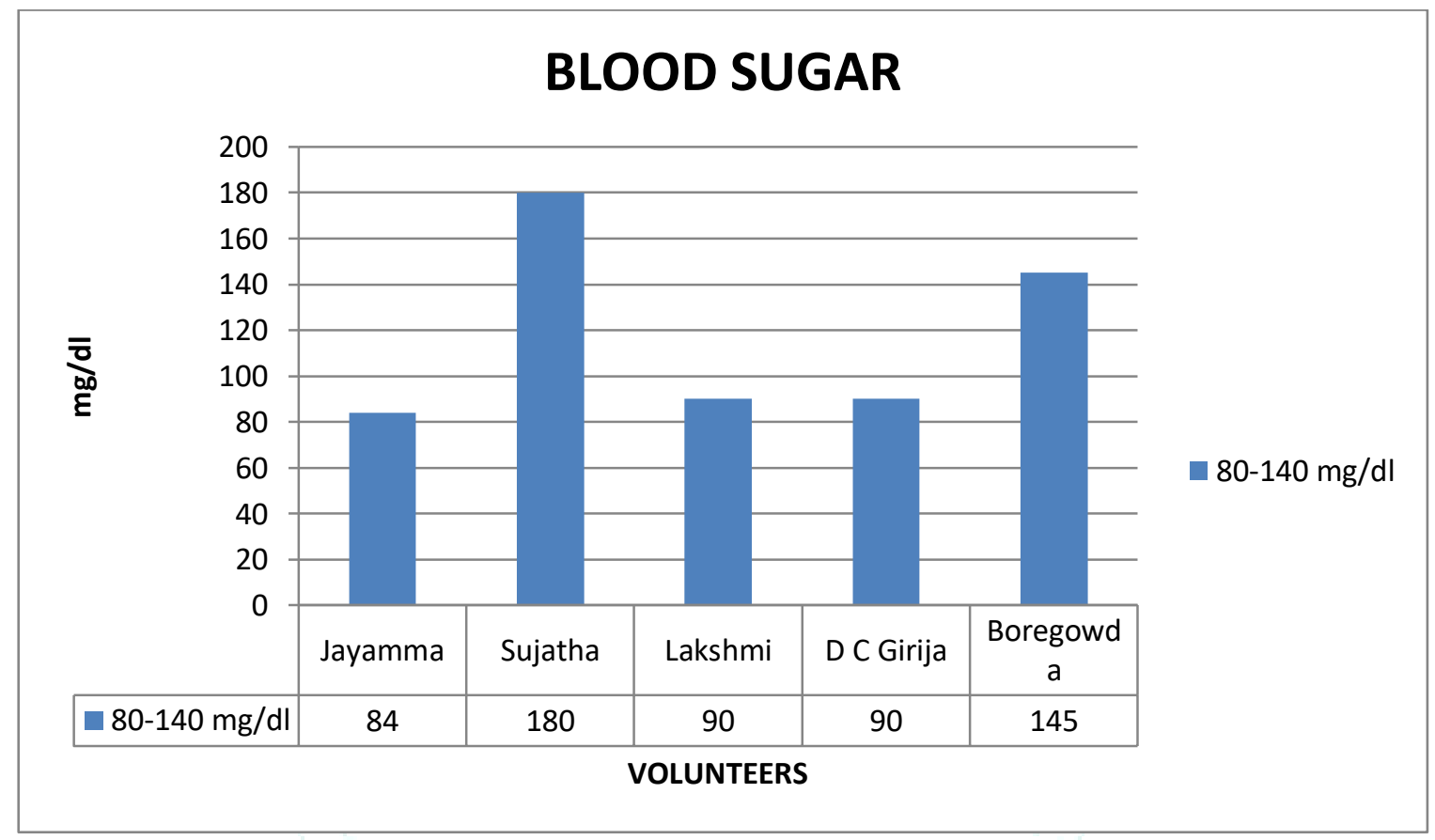

Figure 12: Blood sugar level of the volunteers

\section{ALBUMIN:}

Albumin is a very important protein which is manufactured by the liver, and it is one of the most abundant proteins in our body. It helps in the growth and repairing of the tissue.
In the given graph two of the volunteers were found be having above normal range of the albumin protein in them when compared to the others (Normal range - $3.5-5.2$ $\mathrm{gm} / \mathrm{dl})$.

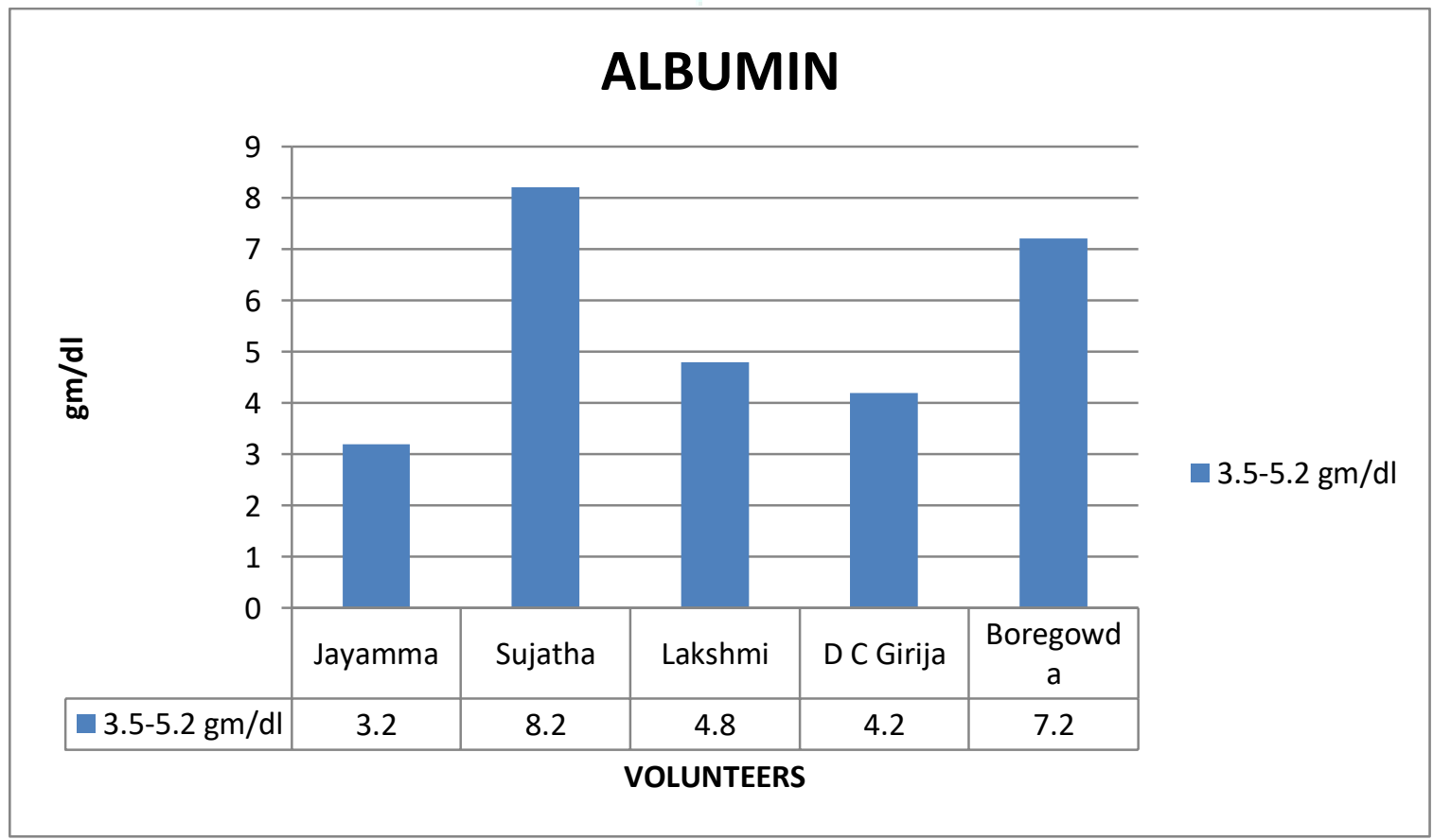

Figure 13: Albumin level of volunteers suffering from Joint Pain 


\section{URIC ACID:}

Uric acid test were done to check its level in the blood. The detection of high level of uric acid in the blood is a sign of condition called Gout, and helps to indentify the cause of frequent kidney stone. The below graph shows us that all the volunteers were found to be in the normal range (Normal range - $2.7 \mathrm{gm} / \mathrm{dl})$.

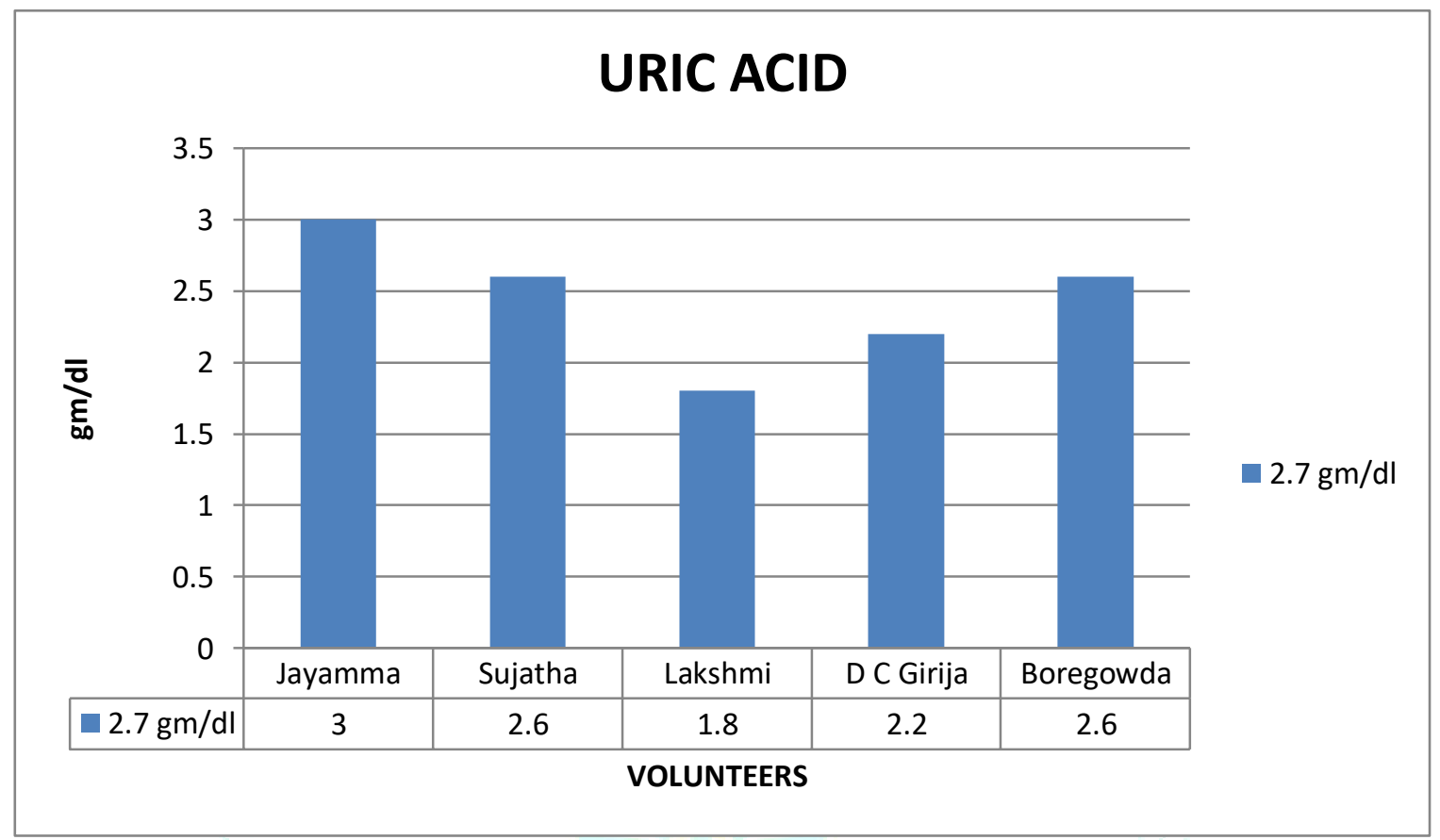

Figure 14: Uric Acid level in the volunteers

\section{RA - FACTOR:}

Rheumatoid arthritis factor test is one of the primarily used to detect rheumatoid arthritis. Rheumatoid factors (RF) are the proteins produced by our immune system that have the capacity to attack the healthy tissue present in our body. In the below graph the level of RA - Factor was consistently decreased when treated with fresh and dry ginger essential oil for a month long period. The normal RA - Factor found in the healthy person is - $20 \mathrm{IU} / \mathrm{ml}$.

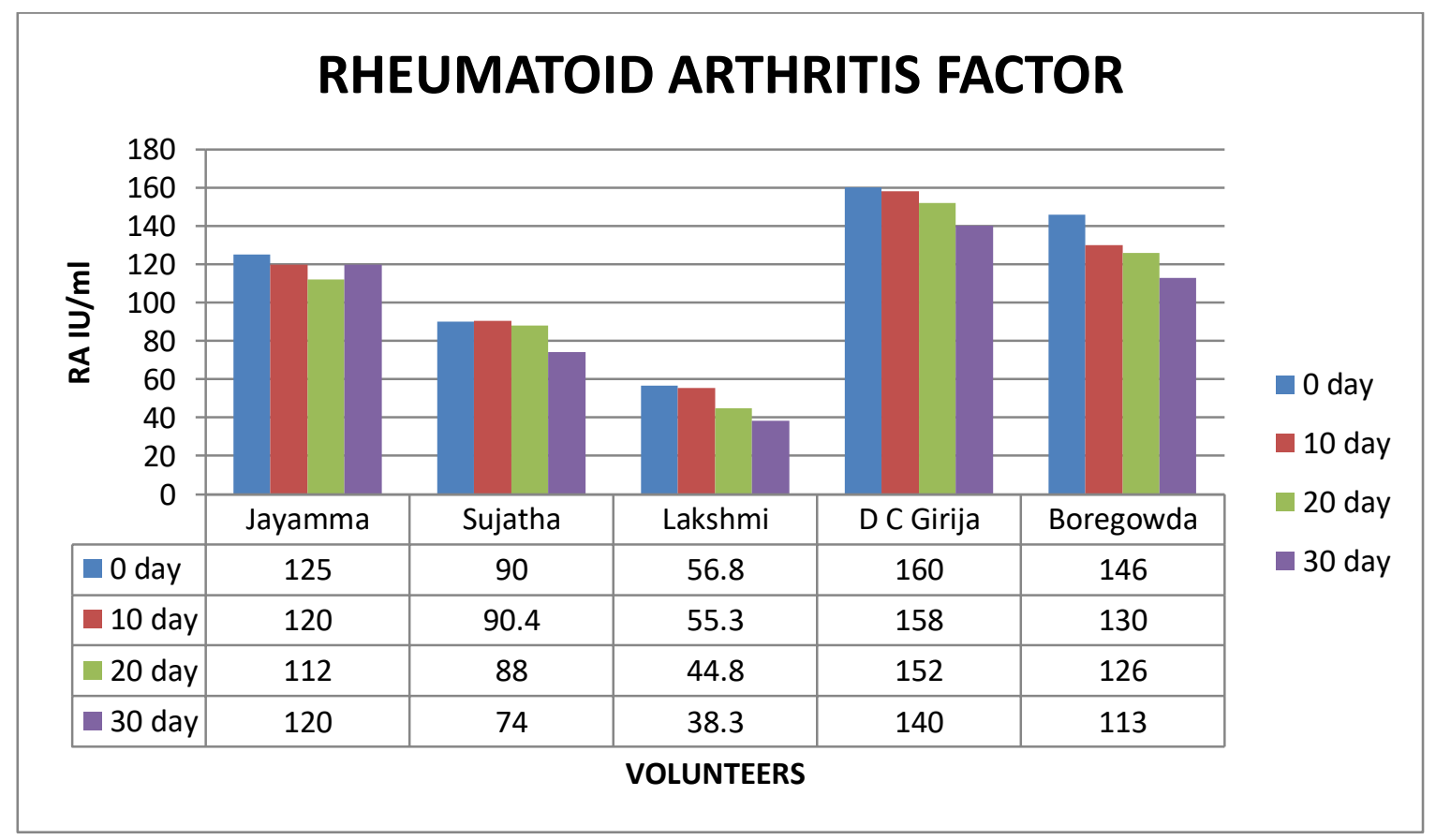

Figure 15: Graph showing in decreasing in RA-Factor in volunteers suffering from Arthritis 


\section{ANTI-STREPTOLYSIN 0:}

Anti-streptolusin $\mathrm{O}$ is an antibody made against Streptolysin 0 . It is a blood test done to check the strep. infection. Streptolysin 0 is an immunogenic, oxygen-liable exotoxic produced by streptococcus bacteria, here " $\mathbf{0}$ " denotes oxygen-liable. The main function of this toxic streptoolysin $\mathrm{O}$ is to cause breaking open red blood cells (haemolysis). The below graph gives us an insight about all the volunteers are in an normal range of 5 to $200 \mathrm{IU} / \mathrm{ml}$. This shows that all the volunteers are not infected by the strep. Bacteria. Normal test value of ASLO is $5-200 \mathrm{IU} / \mathrm{ml}$.

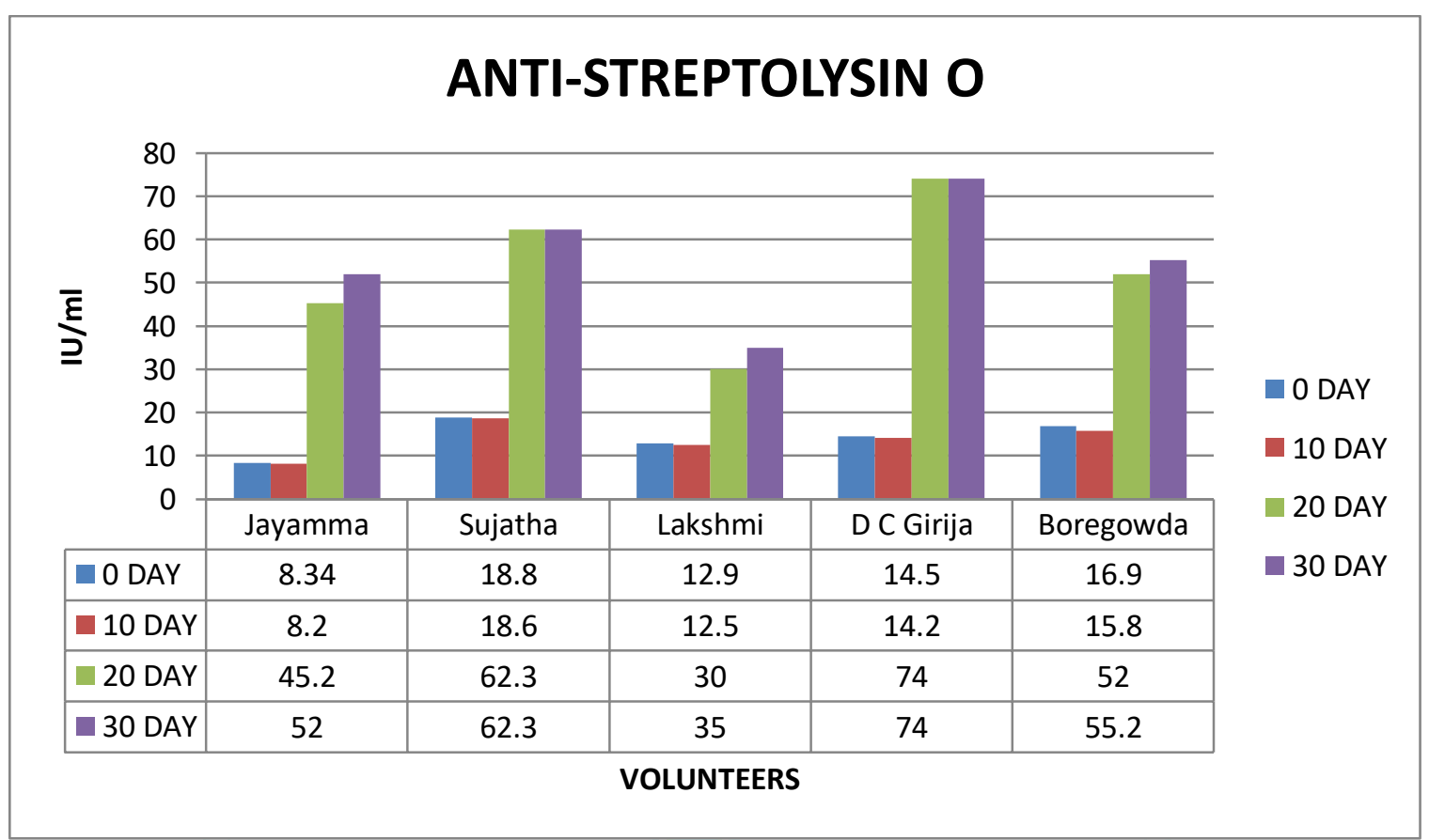

Figure 16: Graph showing the anti-streptolysin 0 an antibody against streptolysis 0 , a toxic enzyme produced by group A Streptococcus bacteria. In varying level in selected volunteers

\section{C- REACTIVE PROTEIN:}

This protein is a ring shaped, pentameric protein found in blood plasma synthesized in the liver. Its concentration usually increases during the time of inflammation. The below graph shows the decreasing concentration of $\mathrm{C}-\mathrm{RP}$ in arthritis induced patients. Applying fresh and dry ginger essential oil for a month period volunteers are reported that they are experiencing less pain to a certain extinct. The graphs justifies the results. Normal range of $\mathrm{C}-\mathrm{RP}$ found is $<0.5-3.0 \mathrm{mg} / \mathrm{dl}$.

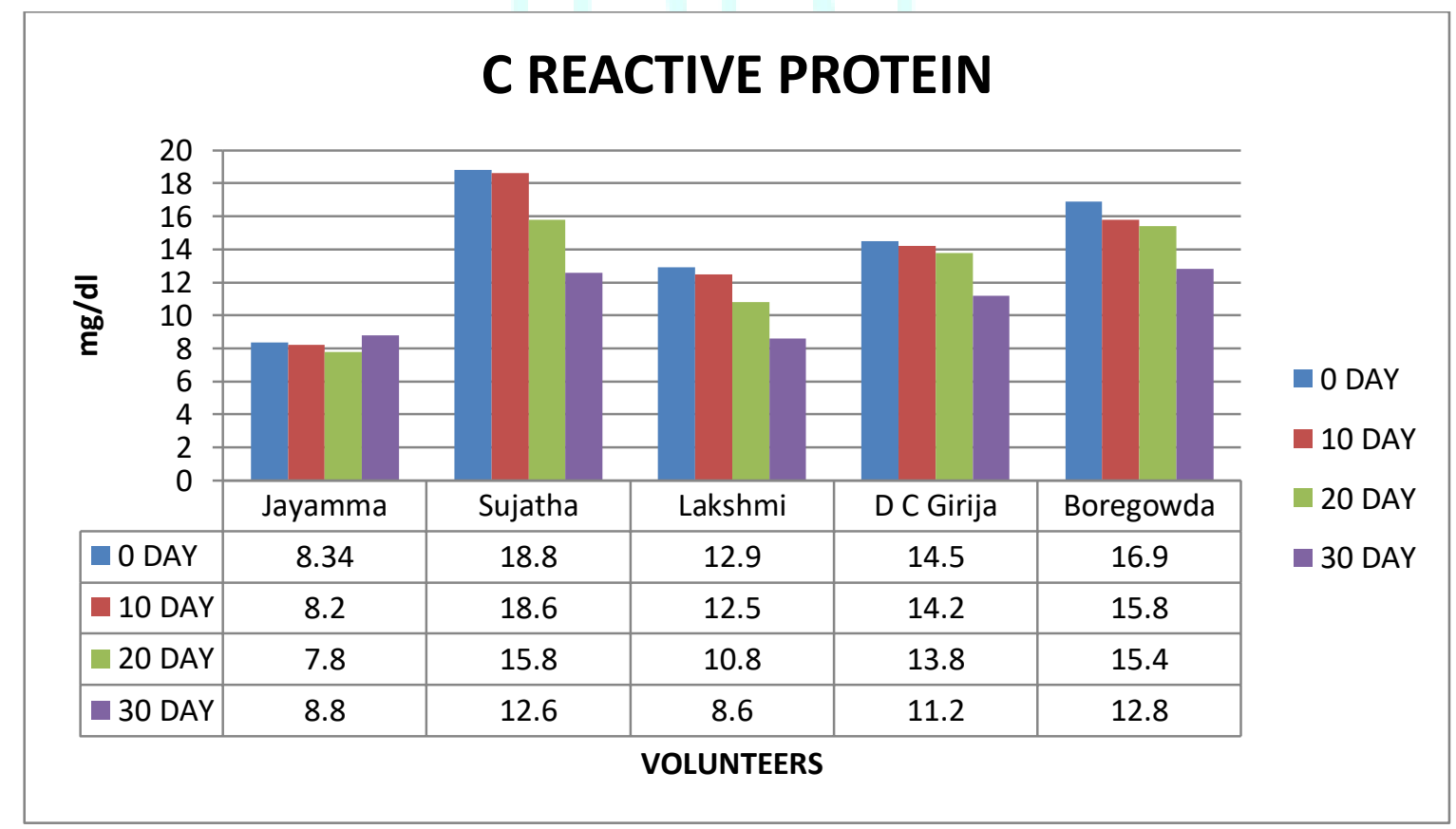

Figure 17: Graph showing in decreasing level of c-reactive protein produced during inflammation after administering with fresh and dry ginger essential oil with freshly prepared ginger medicinal remedy (external apply). 


\section{DISCUSSION}

Ginger an herbaceous plant which is widely used as an ingredient in dietary source. The bioactive compound present in the ginger shows its potential useful nature in developing many therapeutics agents. Ginger is a spices belongs to tropical region reported that it has the properties of antibacterial, antiviral, antifungal, thus this discovery has shown promising way in developing new medications for therapeutic use in humans [25,26]. Applying ginger essential oil could help in decreasing the pro-inflammatory molecules and reducing joint swelling and pain related to it. Many scientific studies findings show that the ginger can be used as one of the pain reducing agent with fewer side effects than modern medications. Thus, herbal medicinal herbs are getting popularity in medicinal field; it can be used as an alternative drug in reducing pain in patients suffering from Arthritis/Joint pain. In this study a calculated dosage of ginger essential oil extract was given to the selected 5 Arthritis affected volunteers for continuously until 30 days to check its effect. Blood was collected after every 10 days after applying the ginger oil daily. We have observed that the $\mathrm{RA}$ and CRP level in the volunteers decreased after $2^{\text {nd }}$ time administration of the ginger oil. Decreasing in ESR, RA, and CRP was observed after 10 days of applying ginger essential oil daily. We can see the gradual decreasing in the proinflammatory molecules by these lab tests (fig: 11, 13, 15).

The haemoglobin level in the affected individuals waschecked to know the variation in $\mathrm{Hb} \%$ in the joint pain affected during month long study (fig: 10). Ginger essential oil may be good remedy for joint pain with the proper use of it can cure join pain related disorders.

We can see the difference in phytochemicals present in different solvents of Zingiber officinale rhizome extract. Six different solvents were used to study the phytochemical availability in the both fresh and dry ginger rhizome, extract solvents used are - Polar solvents: -Water $(\mathrm{H}-\mathrm{OH})$, Methanol ( $\left.\mathrm{CH}_{3}-\mathrm{OH}\right)$, Ethanol $\left(\mathrm{CH}_{3} \mathrm{CH}_{2}-\mathrm{OH}\right)$, Dipolar solvents: - Acetone $\left(\left(\mathrm{CH}_{3}\right)_{2} \mathrm{C}=0\right)$, Ethyle acetate $\left(\mathrm{CH}_{3} \mathrm{CO}_{2} \mathrm{CH}_{2} \mathrm{CH}_{3}\right)$, Non-polar solvent: - Chloroform $\left(\mathrm{CHCl}_{3}\right)$ [58]. The different solvents used to analysis of different bioactive components present in the ginger rhizome all the solvents shows the presence of alkaloids, glycosides terpanoids and volatile oils in them with little in aqueous extract, phenols, steroids were shown presence only in acetone extract, carbohydrates shown presence only in acetone, methane and aqueous extract (Tab: 6 and 7). The current result shows the invite antiinflammatory activity of ginger extraction it was conducted in two methods one is heat induced and another is hypotonicity-induced haemolysis. Anti-inflammatory study in in-vitro carried out by using RBCs because it is analogous to the lysosomal membrane. To control inflammation stabilization of lysosome is important. During inflammation various lysosomal enzymes were produced causing various disorders. The non-steroidal drugs may act by either inhibiting these lysosomal enzymes or by stabilizing the lysosomal membrane[27] The effective inhibition of ginger extract was checked by using aspirin as standard with varying concentration from 100 to $500 \mu$ l. The maximum inhibition for both fresh and dry ginger extract were observed at the concentration of $500 \mu \mathrm{l} / \mathrm{ml}$, ginger essential oil extract showed maximum of $74.6 \& 89.6 \%$ of inhibition in fresh and dry ginger respectively.\% of protection was observed in hypotonicity-induced haemolysis. At the concentration of $500 \mu \mathrm{l} / \mathrm{ml}$ extracted oil showed 84.21 $\$ 73.68 \%$ of protection in fresh and dry ginger respectively, while the standard diclofenac sodium $(100 \mu \mathrm{l} / \mathrm{ml})$ showed $52.63 \%$ inhibition of RBC haemolysis when compared with control (fig: $8 \& 9$ ).
HPLC and SEM were used for the analysis of bioactive compound present in the ginger extracted oil and the affinity of the extracted oil with the silver nanoparticle respectively. The size and shape of the ginger powder extortion were studied (fig: 6 \& 7).

The total phenolic and flavoinds content in the extracted ginger essential oils were studied and the concentration of phenols and flavonoids present in the ginger oils were noted (Tab: 8). This study shows the effectiveness of ginger essential oil in treating various immune related disorders particularly those who suffering from joint pain and its related ailments. It showed that chemically synthesized medication have serious side-effects while using herbal medicinal product may leads to the more effective in treating the diseases with less side-effects. Thus, in recent years much attention were been drawn out in using herbal medicinal products. This work may provide some insight in developing new drug using herbal product present in the nature.

\section{CONCLUSION}

Ginger is a spice which is used in our food source, which expresses its medicinal property upon consumption. For many years ayurveda has mentioned that ginger has the capacity to cure cold, indigestion and some other gastointestainal disorders. As it is used in our daily life it can increase our immune and health aspects. Its antiinflammatory properties can be a bone for s many people which inhibits the pro-inflammatory molecules can reduce the pain it can be a major medication for joint pain disorders, along with all this benefits ginger can boot our body immune system and increase the rate of metabolism by decreasing the triglyceroids and low density cholesterol. Thus, ginger is an herb having minimal known side effects can be used for various health conditions. The decreasing in the pro-inflammatory molecules were initially not found after applying the ginger oil but gradual apply of the ginger oil shows the decreasing in the ESR, CRP and RA-Factor which confirms that the reduction of inflammation in affected individuals.

Zingiber officinale shows difference in the composition of crude extracts is likely due to the varying degree of solubility of active constituents in the solvents used. Different solvents have been reported to have the capacity to extract different phytochemicals depending on their solubility or polarity in the solvents. Acetone extract shows maximum presence of phytochemicals whereas chloroform and aqueous extract shows vary few phytochemicals. The anti-inflammatory activity in in-vitro conditions carried out to study the effectiveness of ginger rhizome extract in inhibiting the proinflammatory molecules and lysis of such cells present on the RBC membrane.

Ginger administration on selected volunteers shows that it can be used as an alternative medication in treating join pain and swelling. The reduction in the level of RA-F, CRP and ESR are observed and studied, this shows the powerful antiinflammatory effect of ginger plant. The spice (ginger) mentioned in ayurveda for its health promoting and immune boosting properties which has the capacity to cure cold, fever, vomiting, anti-inflammatory, anti-diabetic, antitumerous, anti-bacterial, antioxidant and as an appetizer and many more to count. 


\section{REFERENCES:}

01. A.T. Mbaveng, V. Kuete, Zingiber officinale, Medicinal Spices and Vegetables from Africa, Therapeutic Potential against Metabolic, Inflammatory, Infectious and Systemic Diseases, 2017 Jan 14; 627-639. https://doi.org/10.1016/B978-0-12809286-6.00030-3

02. Basil D. Roufogalis, Zingiber officinale (Ginger): A Future outlook on oits potential in prevention and treatment of diabetes and prediabetic states, New Journal of Science, 2014; 01-15. ID: 674684. https://dx.doi.org/10.1155/2014/674684

03. Laleh Khodaie, Omid Sadeghpoor, Ginger from Ancient Times to the new outlook, Jundishpaur Journal of Natural Pharmaceutical Products, 2015; 10(1): e18402. 01-05.

04. Jalal Bayati Zadeh, Nasriallah Moradi Kor, Phyiological and pharmaceutical effects of ginger (Zingiber officinale Roscoe) as a valuable medicinal plant, Pelagia Reasearch Library, European Journal of Experimental Biology, 2014; 4(1): 87-90.

05. Vikas Kumar, Sawinder Kaur, Radhika, Vyas G, Optimization of process for the preparation of antioxidant rich ginger candy by response surface methodology, International Food and Research Journal, 2017; 24(2):483-489.

06. Bhattarai S, Tran V. H, Duke C.C, The stability of gingerol and shogaol in aqueous solution, Journal of Pharmaceutical Science, 2001; 90:1658-1664.

07. Kumar G, Karthik L, Rao B, K. V, A review on pharmacological and phytochemical properties of Zingiber officinale Roscoe (Zingiberaceae), Journal of Pharmacy Research, 2011; 4(9):2963-2969.

08. Bhargava S, Dhabhai K, Batra A, Sharma A, Malhotra B, Zingiber officinale: Chemical and phytochemical screening and evaluation of its antimicrobial activities, Journal of Chemical and Pharmaceutical Research. 2012; 4(1):360-364.

09. Z. Kamaliroosta, L. Kamaliroosta, A.H. Elhamirad, Isolation and identification of ginger essential oil. Journal of Food Biosciences and Technology, 2013 July 10; 73-80.

10. Cragg G.M, Newman D.J, medicinal for the millennia. Annals of the NewYork Academy of sciences. 2001; 9(53):03-25.

11. Jyotsna Dhanik, Neelam Arya, Viveka Nand, A review on Zingiber officinale. Journal of Pharmacognosy and phytochemistry. 2017; 6(3):174-184.

12. Kottarapat Jeena, Vijayastelter B. Liju, Ramadasan Kuttan, Antioxidant, anti-inflammatory and antinociceptive activities of essential oil from ginger. Indian J Physiol Pharmacol. 2013; 57(1):51-62.

13. Julie L. Ryan, Gary R. Morrow, Ginger. Oncology nurse edition. 2010; 24(2):46-49.

14. Badreldin H. Ali, Gerald Blunden, Musbah O. Tanira, Abderrahim Nemmar, Some phytochemical, pharmacological and toxicological properties of ginger (Zinger officinale Roscoe): A review of recent research. Food and Chemical Toxicology. 2008; 46(2):409-420.

15. Brett White, MD. Ginger: An Overview. Complementary and alternative medicine, American Family Physician, 2007; 75:1689-91.
16. Z. Kamaliroosta, L. Kamaliroosta, A.H. Ethamirad, Isolation and Identification of Ginger Essential oil, Journal of Food Biosciences and Technology, 2013; 3:73-80.

17. Jolad S.D, Lantz R.C, Chen G.J, Bates R.B, Timmermann B.N, Commercially processed dry ginger (Zingiber offcinale): composition and effects on LPS- Stimulated PGE2 production. PhytoChemistry. 2005; 66(13):1614-35.

18. Humayun Riaz, Almas Begum, Syed Atif Raza, Zia Mohy-UdDin Khan, Hamad Yousaf, Ayesha Tariq, Antimicrobial peoperty and phytochemical study of ginger found in local area of Punjab, palistan. International Current Pharmaceutical Journal. 2015; 4(7): 405-409.

19. Z. N. Amiri, G.D. Najafpour, M. Mohammadi, A.A. Moghadamnia. Subcritical water extraction of bioactive compounds from ginger (Zingiber officinale Roscoe). International journal of engineering. 2018; 31(12):19912000.

20. V, Jyothiprabha, P. Venkatachalam. Preliminary phytochemical screening of different solvent extracts of selected Indian species. Int. J. Curr. Microbiol. Sci. 2016; 5(2):116-122.

21. Ammar Mohammad A.A, Mawahib ElAmin M.E, Sakina Mohamed Y. Total phenolic and flavonoid contents and antioxidant activity of ginger (Zingiber officinale Rosc.) rhizome, callus and callus treated with some elicitors. Journal of genetic engineering and biotechnology. 2018; 01-06. DOI: 10.1016/j.jgeb.2018.03.003

22. G.leelaprakash, s. Mohan Dass. Invitro anti-inflammatory activity of methanol extract of enicostemmaaxillare. International journal of drug development and research. 2010; 3(3):189-196.

23. Samy R.P, Ignacimuthu S, Antibacterial activity of some folklore medicinal plants used by tribals in Western Ghats in India, J of Ethnopharmacol, 2000; 69:63-71.

24. Rajendra V, Lakshmi K.S. In vitro and in-vivo antiinflammatory activity of leaves of symplocos cochinchinensis (Lour) Moore ssp Laurina. Bangladesh J Pharmacol. 2008; 3: 121-124.

25. Samy R.P, Ignacimuthu S, Antibacterial activity of some folklore medicinal plants used by tribals in Western Ghats in India, J of Ethnopharmacol, 2000; 69:63-71.

26. Paini S.W, Tarsisius Dwi W.B, Fenny A.K, EvelynL.W. Difference of solvent polarity to phytochemical content and antioxidant activity of Plucheaindicia Less leaves extracts. International journal of pharmacognosy and phytochemical research. 2014; 6(4):850-855.

27. Rajendra V, Lakshmi K.S. In vitro and in-vivo antiinflammatory activity of leaves of symplocos cochinchinensis (Lour) Moore ssp Laurina. Bangladesh J Pharmacol. 2008; 3:121-124. 